\title{
Histological alterations and polycyclic aromatic hydrocarbon exposure indicative bile fluorescence patterns in fishes from Koggala lagoon, Sri Lanka
}

\author{
R.A.T.C.S. Ranasingha and Asoka Pathiratne* \\ Department of Zoology and Environmental Management, Faculty of Science, University of Kelaniya, Kelaniya.
}

\begin{abstract}
The Koggala lagoon is a coastal wetland affected by a major oil spill and other anthropogenic pollution sources. In this study, gill and liver histological alterations and polycyclic aromatic hydrocarbon (PAH) exposure indicative bile fluorescence patterns of the fish species inhabiting the lagoon were examined in order to explore the potential biological impacts. Fixed wavelength fluorescence patterns in the bile of Mugil cephalus, Lutjanus russellii and Etroplus suratensis showed bioavailability of naphthalene type-, phenanthrene type-, pyrene type- and benzo(a)pyrene type- metabolites indicating recent exposure of the fishes to petrogenic and pyrogenic PAHs. Histological analysis revealed the occurrence of prominent gill and liver lesions, especially in the tissues of $M$. cephalus and L. russellii. Of the fish species examined, which included 43 individual fishes, the liver tissues of M. cephalus (two fish) and L. russellii (one fish) displayed foci of hepatocellular alterations with nodular hyperplasia. This is the first record on pre-tumor type hepatic lesions seen in fishes living in Sri Lankan waters. This study provides scientific evidence for the biological impacts on the resident fishes in the Koggala lagoon, and calls for further research on the impacts of coastal water pollution in Sri Lanka and potential management strategies.
\end{abstract}

Keywords: Coastal pollution, fish histology, Koggala lagoon, oil spill.

\section{INTRODUCTION}

Lagoons and estuaries are the most vulnerable ecosystems to oil contaminations due to oil spills in the open sea. The oil slicks can drift towards the shore and further into the estuaries and lagoons (Jernelo“v, 2010). The components in fuel oil that have been mainly associated with high health risks are the polycyclic aromatic hydrocarbons
(PAHs). PAHs are a large group of organic compounds with two or more fused aromatic rings. Apart from oil spills and discharges, other anthropogenic sources of PAHs in the aquatic environment include industrial and municipal wastewater, refuse incineration and internal combustion engines. PAHs tend to be quickly adsorbed to particles and accumulate in sediments (Srogi, 2007). Studies on oil spill effects in tropical and subtropical waters indicate that there have been types of short-term effects that led to long-term damage that had not been seen in cold or temperate waters (Jernelo“v, 2010).

Fishes are considered as indicators of environmental and ecological changes within estuaries (Whitfield \& Elliott, 2002). PAHs are absorbed by fish via the gills, body surface and through ingestion of food and contaminated sediment. In the fish liver PAHs are rapidly transformed into more hydrophilic metabolites that are excreted mainly into the bile, thus the fish exposed to these compounds show only trace amounts of PAH in their tissues (van der Oost et al., 2003). Exposure of fish to PAHs can be assessed by the presence of PAH metabolites in fish bile, where they are concentrated and stored prior to excretion. The levels of fluorescent aromatic compounds in bile detected by the fixed wavelength fluorescence (FF) technique has proven to be a simple and sensitive method for screening $\mathrm{PAH}$ contamination in fish, especially to discern between sites of varying PAH exposure (van der Oost et al., 2003). PAHs comprise the largest class of chemical compounds known as cancer causing agents (Srogi, 2007). Depending on the chemical structure and the level of exposure, PAHs and their metabolites are putative toxic products that lead to mutagenic and/or carcinogenic effects (Srogi, 2007). 
Biomarker studies addressing the impacts at histological and cellular levels of organization are important to establish the cause and effect relationships between the exposure to contaminants and the adverse health of organisms (Picado et al., 2007; Mohamad, 2009). Additionally, histological biomarkers provide powerful tools to detect and characterize the biological end points of a toxicant and carcinogen exposure (Teh et al., 1997; Leonardi et al., 2009; Pinkney et al., 2011). Despite several accidental oil spills, which occurred in the marine environment in Sri Lanka, not much attention has been given to investigate the ecotoxicological impacts of oil spills on Sri Lankan coastal ecosystems. The Koggala lagoon was affected by a major oil spill, which occurred on $8^{\text {th }}$ September 2006 as a result of the sinking of the Bangladesh merchant vessel, 'Amaanat Shah', 9 nautical miles (NM) away at $90 \mathrm{~m}$ depth off the Southern coast of Sri Lanka. Due to this incident, a considerable amount of oil entered the Koggala lagoon with the tidal currents (Jayasiri \& Wijeratne, 2008). In addition, the lagoon is being polluted by multiple anthropogenic activities. Motor boats operated in the lagoon are becoming an additional sources of oil contamination. The lagoon also receives domestic waste and industrial effluents. The Koggala Export Processing Zone, largely focused on textile manufacturing is located within the catchment area of the lagoon (Gunaratne et al., 2010). Over the past two decades, industrialization, urbanization and deforestation have led to wetland loss in the Koggala lagoon area, resulting in the alteration of the relationship of coastal wetlands with the regional environment (Gunaratne et al., 2010). However, biological impacts associated with the Koggala lagoon are not known. The objective of the present study was to explore the biological impacts in the Koggala lagoon using PAH indicative biliary fluorescence patterns and histological alterations in gills and liver tissues of the fish species inhabiting the lagoon.

\section{METHODS AND MATERIALS}

\section{Site description and fish collection}

The Koggala Lagoon is located $\left(5^{\circ} 58^{\prime}-6^{\circ} 20^{\prime} \mathrm{N}\right.$ and $80^{\circ} 17^{\prime}-80^{\circ} 22^{\prime} \mathrm{E}$ ) on the Southern coast of Sri Lanka and covers 727 ha with its depth ranging from $1.0-3.7 \mathrm{~m}$. The waterway area of the Koggala lagoon is estimated approximately as $7.27 \mathrm{~km}^{2}$, measuring $4.8 \mathrm{~km}$ in length and $2 \mathrm{~km}$ in width. The lagoon opens to the sea from the Southern side by a narrow $300 \mathrm{~m}$ long canal called Pol Oya. The lagoon receives fresh water from 4 main streams that enter the lagoon from the North-West side/ Northern side (Gunaratne et al., 2010). Small-scale fishing industry exists within the lagoon.
In the present study, two sampling areas of the lagoon were selected (Figure 1). The Southern site is located close to the seaward side, which includes the Pol Oya and the area behind the Madol Duwa (5 $5^{\circ} 59.054^{\prime} \mathrm{N}, 80^{\circ} 20.163^{\prime} \mathrm{E}-$ $\left.5^{\circ} 59.275^{\prime} \mathrm{N}, 80^{\circ} 20.208^{\prime} \mathrm{E}\right)$. The Northern site is located towards the innermost landward side $\left(6^{\circ} 1.108^{\prime} \mathrm{N}, 80^{\circ}\right.$ $\left.19.143^{\prime} \mathrm{E}-6^{\circ} 1.188^{\prime} \mathrm{N}, 80^{\circ} 19.286^{\prime} \mathrm{E}\right)$, which includes the area that receives freshwater inputs. The sampling sites were visited on two occasions in 2010 (22 $2^{\text {nd }}$ June and $28^{\text {th }}$ July). General physico-chemical parameters of water (temperature, $\mathrm{pH}$, salinity, conductivity, dissolved oxygen) in three sub-locations in each site were measured in situ using YSI 556 MPS, Multi Probe System (YSI Environmental, Yellow Springs, OH, USA). The fish, depending on their availability were captured using cast nets from the study sites in the early morning with the help of fishermen. Mugil cephalus (Grey mullet) and Lutjanus russellii (Russell's snapper) were collected from the Southern site of the lagoon where as Etroplus suratensis (Pearlspot) and Oreochromis mossambicus (Mozambique tilapia) were collected from the Northern site of the lagoon. The fish were transported to the laboratory within 6 hours, in polythene bags filled with well oxygenated water collected from the same site.

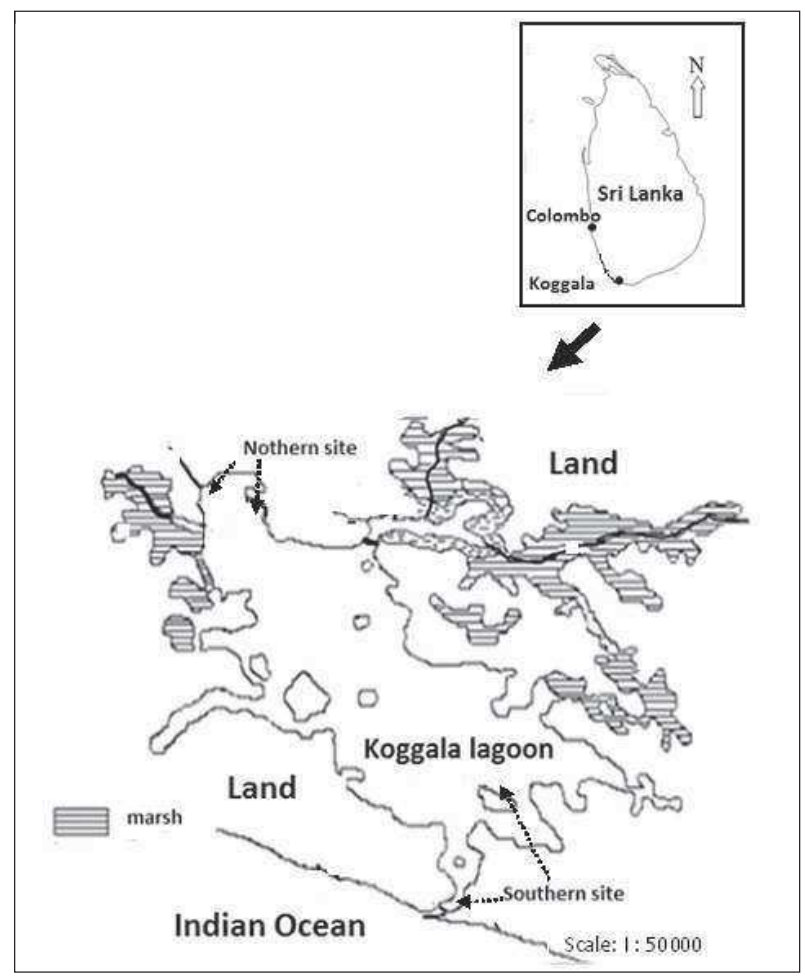

Figure 1: The map of Koggala lagoon showing the location of sampling areas: Southern site (towards the seaward side) and land bound Northern site (Map modified from CEA, 1995) 


\section{Analysis of bile fluorescence patterns}

In the laboratory, the fishes were anesthetized using benzocaine, $9-10$ hours after capturing them in order to allow bile accumulation. The bile was collected by puncturing the gall bladder and frozen at $-80{ }^{\circ} \mathrm{C}$ until further processing. Bile fluorescence patterns were determined by fixed wavelength fluorescence technique using computer controlled Varian Cary Eclipse fluorescence spectrophotometer. Bile $(2 \mu \mathrm{L})$ diluted in $4 \mathrm{~mL}$ of $48 \%$ ethanol was used to decrease quenching of the fluorescence signal. The fixed wavelength fluorescence of the bile samples at the excitation/ emission wavelength pairs $290 / 335 \mathrm{~nm}, 341 / 383 \mathrm{~nm}$ and $380 / 430 \mathrm{~nm}$ were determined for naphthalene typepyrene type- and benzo(a)pyrene type- metabolites, respectively as described by Aas et al. (2000). Fixed wavelength fluorescence at the wavelength pair $260 / 380 \mathrm{~nm}$ was used for the detection of phenanthrene type-metabolites (Krahn et al., 1993). Slit widths were set at $2.5 \mathrm{~nm}$. The fluorescence values were obtained as arbitrary fluorescence units after deducting the signal level of the solvent.

\section{Histology}

Gill and liver tissues of the fishes were preserved in neutral buffered formalin and were processed using standard histological methods (Bucke, 1998). The processed samples were embedded in paraffin wax and sections of $0.5 \mu \mathrm{m}$ thickness were cut and stained with haemotoxyline and eosin. The stained sections were observed under the bright field microscope for the examination of histological structure of the gills and liver of fish in comparison to the normal histological appearance in the fish tissues as described by Hibia (1982). Severity of the histological alterations was also recorded categorically. The presence of parasites (if any) and associated histological changes were also recorded. Occurrence of prominent foci with hepatocellular alterations in the liver tissues was diagnosed following the descriptions given for other species of fish (Boorman et al., 1997; Stentiford et al., 2003; Lerebours et al., 2013). Specific areas of cellular alterations in the liver were measured using the image analysis software (CellSense version 1.6 Imaging Software, Olympus Corporation, Tokyo, Japan).

\section{Data analysis}

Site specific differences in the general physicochemical parameters of water were analysed by Students $t$ test (Zar, 1999). For the analysis of species specific bile fluorescence patterns of fish, the data obtained from each fish collected during the two sampling events were pooled with respect to a particular fish species before analysis using one way analysis of variance (ANOVA). Where differences were significant $(\mathrm{p}<0.05)$, multiple comparisons were carried out by Tukey's test. Log transformed data $\left[\log _{10}(x+1)\right]$ was used for statistical analysis.

\section{RESULTS}

\section{Physico-chemical characteristics of water}

The measured physico-chemical parameters of the lagoon water are presented in Table 1. Salinity and conductivity levels were significantly higher $(p<0.05)$ at the Southern site (seaward site) compared to the Northern site (innermost landward site). No significant variations were found in relation to other water quality parameters measured during the study period.

\section{PAH exposure indicative bile fluorescence patterns in the fish}

The fluorescence patterns corresponding to naphthalene type-, phenanthrene type-, pyrene type- and benzo(a)pyrene type- metabolites detected in the fish

Table 1: Physicochemical parameters of water in the sampling sites of the Koggala lagoon during the study period

\begin{tabular}{lcc}
\hline Parameter & Southern site & Northern site \\
\hline Temperature $\left({ }^{\circ} \mathrm{C}\right)$ & $29 \pm 1(29-31)$ & $29 \pm 2(27-30)$ \\
$\mathrm{pH}$ & $8.2 \pm 0.5(7.7-8.7)$ & $8.0 \pm 0.1(7.9-8.2)$ \\
salinity $\left(\mathrm{g} \mathrm{L}^{-1}\right)$ & $35 \pm 12(15-49)^{*}$ & $3 \pm 1(2-4)$ \\
Conductivity $\left(\mathrm{mS} \mathrm{cm}^{-1}\right)$ & $1038 \pm 76(871-1093)^{*}$ & $577 \pm 423(89-647)$ \\
Dissolved oxygen $\left(\mathrm{mg} \mathrm{L}^{-1}\right)$ & $3.5 \pm 0.5(2.8-4.1)$ & $3.8 \pm 1.8(2.5-5.9)$ \\
\hline
\end{tabular}

Data are presented as mean \pm SD and range, $\mathrm{n}=6$

*Significantly different from the Northern site $(\mathrm{p}<0.05)$ 


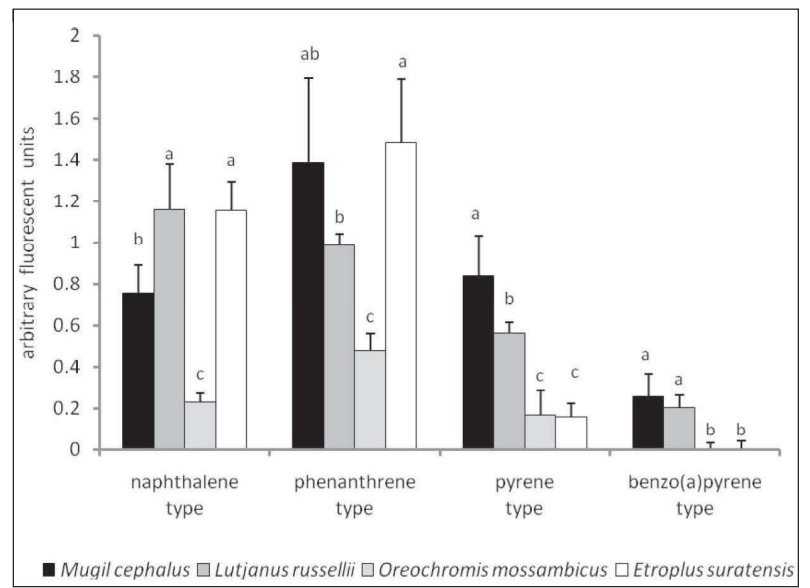

Figure 2: Polycyclic aromatic hydrocarbon exposure indicative bile fluorescence patterns of fish species captured from the Koggala lagoon, corresponding to naphthalene type, phenanthrene type, pyrene type and benzo(a)pyrene type metabolites. Data are presented as mean \pm SD $(n=4-21)$. $\log (\mathrm{x}+1)$ transformation was used for statistical analysis of data. For each metabolite type, bars with different superscript letters are significantly different from each other (ANOVA, Tukey's test, $\mathrm{p}<0.05$ ). species examined are shown in Figure 2. The highest bile fluorescence levels related to naphthalene typemetabolites were detected in the bile of L. russellii collected from the Southern site and E. suratensis collected from the Northern site. The fluorescence corresponding to phenanthrene type- metabolites were higher in M. cephalus and L. russellii captured from the Southern site and E. suratensis captured from the Northern site. Bile fluorescence values related to pyrene type- and benzo(a)pyrene type- metabolites were higher in the bile of M. cephalus and L. russellii captured from the Southern site in comparison to the other two fish species from the Northern site $(\mathrm{p}<0.05)$. In general, bile fluorescence corresponding to the PAH types tested was the lowest in O. mossambicus collected from the Northern side of the lagoon.

\section{Histological alterations in the gills and liver tissues}

The gills of fish species captured from the Koggala lagoon showed prominent histopathological changes including primary and secondary gill lamellae hyperplasia, fusion of lamellae, enlargement of the apical portion of the secondary lamellae forming club shaped deformed

Table 2: Occurrence of histological alterations in the gills and liver tissues of four fish species collected from the Koggala lagoon during the study period

\begin{tabular}{|c|c|c|c|c|}
\hline Characteristics & Mugil cephalus & Lutjanus russellii & $\begin{array}{l}\text { Oreochromis } \\
\text { mossambicus }\end{array}$ & $\begin{array}{l}\text { Etroplus } \\
\text { suratensis }\end{array}$ \\
\hline Number of fish examined & 21 & 4 & 12 & 6 \\
\hline Total length $(\mathrm{cm})$ & $18.5 \pm 3.9$ & $15.4 \pm 2.1$ & $18.8 \pm 2.3$ & $15.6 \pm 1.5$ \\
\hline Body weight (g) & $79 \pm 49$ & $43.9 \pm 16.4$ & $106.2 \pm 35.1$ & $41.7 \pm 1.9$ \\
\hline \multicolumn{5}{|l|}{ Number of fish with gill tissue alterations } \\
\hline Primary lamellae bifurcations & $2(++)$ & 0 & 0 & 0 \\
\hline Secondary lamellae hyperplasia and fusion & $21(++$ to +++$)$ & $4(+$ to ++$)$ & $2(+$ to ++$)$ & $4(+$ to ++$)$ \\
\hline Secondary lamellae aneurism & $21(++$ to +++$)$ & $4(+$ to +++$) 0$ & 0 & $3(+$ to ++$)$ \\
\hline Secondary lamellae epithelial lifting & $5(++)$ & 0 & 0 & 0 \\
\hline Mucous cell proliferation & $21(+++)$ & $3(+$ to +++$)$ & $2(+$ to ++$)$ & $4(+$ to ++$)$ \\
\hline Ectoparasitic copepod infestations & 5 & 0 & 0 & 0 \\
\hline Ectoparasitic fluke infestations & 0 & 0 & 2 & 2 \\
\hline \multicolumn{5}{|l|}{ Number of fish with liver tissue alterations } \\
\hline Sinusoid dilation and congestion & $10(+$ to +++$)$ & $4(+$ to +++$)$ & $2(+$ to ++$)$ & $3(++$ to +++$)$ \\
\hline Hepatocyte vacuolation & $10(++$ to +++$)$ & $4(++$ to +++$)$ & $1(+$ to ++$)$ & $3(++$ to +++$)$ \\
\hline Altered hepatocellular hyperplastic foci & $2(+++)$ & $1(++)$ & 0 & 0 \\
\hline Pleomorphic hepatocellular nuclei & $15(++$ to +++$)$ & $2(+$ to ++$)$ & 0 & 0 \\
\hline Melanomacrophage centres & $1(++)$ & $2(++)$ & $5(++)$ & $3(++)$ \\
\hline
\end{tabular}

Body size data are presented as mean $\pm \mathrm{SD}$ of the number of fish examined.

The severity of alterations is graded as mild $(+)$, moderate $(++)$ and severe $(+++)$. 
ends (aneurism), epithelial lifting and mucous cell proliferation. The severity of the pathological conditions varied depending on the fish species (Table 2). Most of the gill lamellae of M. cephalus collected from the Southern site showed prominent primary and secondary gill lamellae hyperplasia, aneurism and severe mucous cell proliferation. Two individuals of $M$. cephalus displayed primary gill lamellar bifurcations. Of the 21 M. cephalus collected from the Southern site, the gills of five individuals had copepod parasite infections (Figure $3)$. Ectoparasitic flukes were found attached to the gills of E. suratensis and $O$. mossambicus collected from the

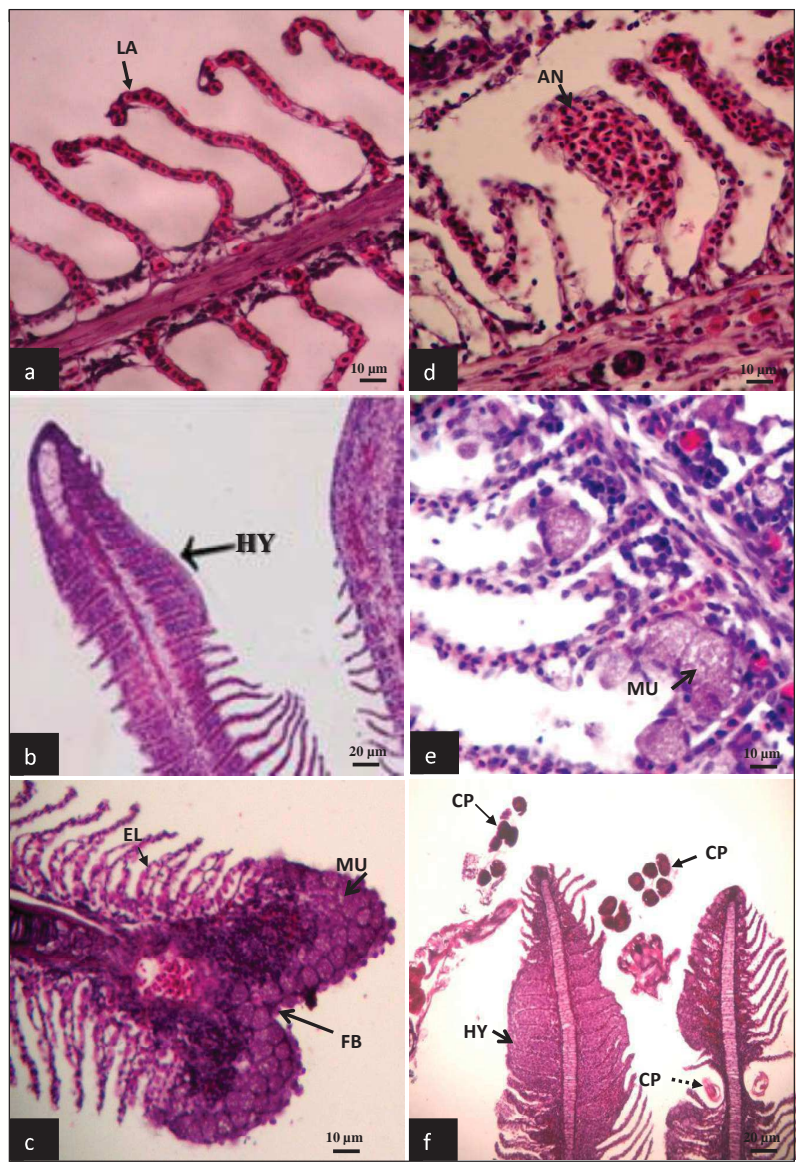

Figure 3: Histological structure of gills of Mugil cephalus collected from Southern site of the Koggala lagoon (a) normal gill lamellae (LA); (b) gill lamellae showing hyperplasia and lamellar fusion (HY); (c) primary gill lamellae with bifurcation at the tip (FB), proliferated mucus cells (MU) and epithelial lifting (EL); (d) gill lamellae showing aneurism (AN) with congested erythrocytes; (e) primary gill lamellae with severe mucus cell proliferation; (f) gill lamellae with copepod parasite infestation (CP) showing hyperplasia and lamellar fusion (HY) and mechanical defromation of the gill lamellae (dashed arrow).
Northern site. Structural alterations associated with the attachment of the parasites in the gills of these fish were hyperplasia and displacement of the normal architecture of the gill lamellae.

The liver tissues of fish species collected from the Koggala lagoon showed prominent histopathological alterations including dilated sinusoids congested with blood cells and hepatocellular vacuolations (both macrovesicular steatosis and microvesicular steatosis). The severity of pathological conditions of the liver varied depending on the fish species (Table 2). The liver of

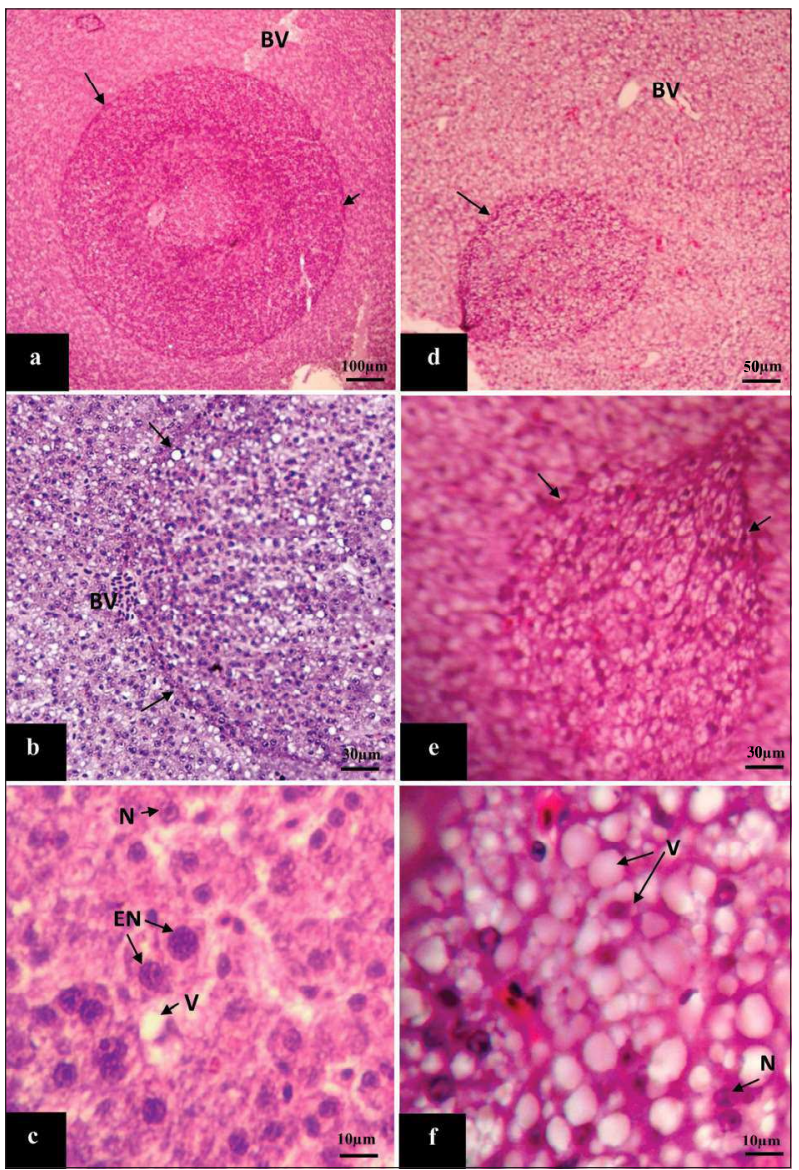

Figure 4: Liver tissues of Mugil cephalus (a - c) collected from Southern site of the Koggala lagoon showing conspicuous hyperplastic hepatocellular foci with prominent boundaries (shown by arrows) with enlarged hepatocellular nuclei; liver tissue of L. russellii (d - f) showing conspicuous hyperplastic vacuolated hepatocellular foci with prominent boundaries (shown by arrows)

BV: blood vessel, EN: hepatocytes with enlarged nucleus; $\mathrm{N}$ : hepatocytes with normal nucleus, $\mathrm{V}$ : micro and macrovacuolations. 
M. cephalus fish also displayed pleomorphic nuclei. Of the 21 M. cephalus collected from the Southern site, the liver sections of two individuals displayed conspicuous basophilic hepatocellular foci with hyperplasia (366 $-968 \mu \mathrm{m}$ in diameter and $186014-702094 \mu \mathrm{m}^{2}$ in area), which can be considered as nodular hyperplasia as the group of cells is more circumscribed and compression of adjacent cells was apparent (Figure 4). In addition, of the four L. russellii examined, the liver of one individual contained conspicuous hyperplastic hepatocellular foci with $\left(180-467 \mu \mathrm{m}\right.$ in diameter and 38501-170714 $\mu \mathrm{m}^{2}$ in area) extensive cytoplasmic vacuolar degeneration (Figure 4). These vacuolated foci appear to be associated with lipids and had prominent boundaries. Livers of the three E. suratensis collected from the Northern site also had severe sinusoid congestion and hepatocellular vacoulations. However, altered hepatocellular foci were not observed in the fish collected from the Northern site. Considering the overall tissue alterations of the four fish species examined minimum tissue alterations were seen in O. mossambicus collected from the Northern site of the lagoon.

\section{DISCUSSION}

Biomarker responses in fish have been successfully employed in recent studies to evaluate oil pollution and diagnose the ecological impact of several oil spills that occurred in the past in different areas of the world (Morales-Caselles et al., 2006; Vuorinen et al., 2006; Dama'sio et al., 2007). The present study explored the biological impacts on resident fish species in the Koggala lagoon, four years after the occurrence of a major oil spill by employing selected biomarkers: PAH exposure indicative bile fluorescence metabolite patterns and histology of gill and liver tissues. PAHs comprise the largest class of chemical compounds known to be carcinogens. Some, while not carcinogenic, may act as synergists. The US Environmental Protection Agency (USEPA) has categorized sixteen PAHs under the group 'priority pollutants', which include naphthalene, phenanthrene, pyrene, and benzo(a)pyrene (Srogi, 2007).

Anthropogenic sources of PAHs are normally categorized as being of pyrogenic (four or more ringed) or petrogenic type (less than four ringed); the former involves processes of incomplete combustion of organic materials and fuels, whereas the latter involves the environmental release of crude oil or petroleum products (Srogi, 2007). In the present study, analysis of fixed fluorescence patterns in the bile showed bioavailability of naphthalene type (two ringed), phenanthrene type (three ringed), pyrene type (four ringed) and benzo(a)pyrene type (five ringed) PAHs in the field captured fish species from the Koggala lagoon, indicating recent exposure of these fishes to petrogenic and pyrogenic PAHs. Potential PAH contamination sources of the lagoon may include fuel oil contamination from the motor boats operated at the lagoon for tourism, storm water runoff, atmospheric deposition and residual PAHs from the major oil spill, which occurred in 2006 along the Southern coast of Sri Lanka. In a recent review on the threats from oil spills, it has been pointed out that some fractions of the oil are fairly persistent and resist both photo- and biochemical degradation for a long time (Jernelo"v, 2010). This is the first time that demonstrated the bioavailability of PAHs in fish residing in the Koggala lagoon. Further studies are needed to quantify the profile of PAHs in different environmental fractions of the lagoon including the sediment and water, in order to identify the main source(s) of PAH contamination in the lagoon environment. Of the four species studied, M. cephalus and L. russellii collected from the seaward site of the lagoon as well as E. suratensis collected from the innermost landward site of the lagoon displayed significantly higher bile fluorescence levels corresponding to naphthalene and phenanthrene type metabolites in comparison to O. mossambicus captured from the innermost landward site of the lagoon. Pyrene type- and benzo(a)pyrene type- metabolites indicative fluorescence signals were significantly higher in M. cephalus and L. russellii captured from the seaward site of the lagoon in comparison to the fishes captured from the innermost landward site. These differences can be due to the combinations of abiotic and biotic factors including differences in the habitat characteristics, feeding ecology, PAH metabolizing capacity and life history patterns of the four species. Diet and feeding ecology patterns indicate that M. cephalus and L. russellii are benthic organism feeders: M. cephalus feeds on detritus and benthic organisms; L. russellii feeds on benthic invertebrates and fish (FishBase, 2014). E. suratensis (adult) is a plant and zoobenthos feeder (FishBase, 2014). High PAH metabolite indicative fluorescence signals detected in these three fish species may be related to the feeding ecology. In a study on Mediterranean fish species that occur in different habitats and represent different trophic strategies, it was found that the type of diet (feeding on the suprabenthic community) was an important factor for enhancing PAH exposure in fish from deep and shallow communities (Insausti et al., 2009). Comparatively low PAH indicative fluorescence patterns seen in the bile of $O$. mossambicus in this study may be attributed to the herbivorous and detritivorous feeding habit of the adult (FishBase, 2014). Depending on the chemical structure and level of exposure, PAHs and their metabolites are putative toxic products that could lead 
to mutagenic and/or carcinogenic effects (Srogi, 2007). Hence in the Koggala lagoon the resident fishes that are exposed to high levels of PAHs are at risk of developing ill health conditions.

The gills of fish are considered as the primary target of waterborne contaminants (Poleksić \& MitrovićTutundžić, 1994). In the present study gill tissue alterations observed in the captured fishes were primary lamellae bifurcations, primary and secondary lamellae hyperplasia, lamellae fusion, aneurism, epithelial lifting and mucous cell proliferation. Among those mucous cell proliferation, lamellar hyperplasia and aneurism were the most prominent alterations seen in M. cephalus and L. russellii captured from the seaward site in comparison to the fishes captured from the inner landward site. Pollution stress as well as ectoparasitic infections seen in the gills could have contributed to the gill lesions observed in the fishes examined. Gill structure alterations such as aneurysm, lamellae disorganization and hyperplasia have been previously observed in several fish species exposed to oil under laboratory and field conditions (Akaishi et al., 2004; Simonato et al., 2008). In fish, vital functions are performed by the gills including respiration, osmoregulation and waste excretion (Poleksić \& Mitrović-Tutundžić, 1994). The gill lesions observed in this study could lead to impairments of normal functioning of the gills of the fishes inhabiting the Koggala lagoon.

Liver is the major organ of accumulation, biotransformation and excretion of contaminants in fish. Liver histopathology has been used as a biomarker of environmental stress since it provides a definite biological end-point of historical exposure (Stentiford et al., 2003; Fernandes et al., 2007; Leonardi et al., 2009). The presence of PAHs in the environment has been associated with the prevalence of tumors in fish livers (Harshbarger \& Clark, 1990; Myers et al., 1991). In the present study, liver lesions observed in the captured fishes from the lagoon were, sinusoid congestion and dilation (circulatory disturbances), melanomacrophages (inflammatory disturbances), hepatocyte vacuolation (regressive disturbances) and foci of hepatocellular alterations (progressive changes). Most of the liver alterations were observed in fishes collected from the seaward site of the lagoon. The liver sections of two M. cephalus individuals from the seaward site displayed conspicuous hyperplastic hepatocellular foci with distinctive borders that can be considered as nodular hyperplasia, as the group of cells was more circumscribed and compression of adjacent cells was apparent. The liver tissue of one L. russellii individual displayed vacuolated foci with distinctive borders. These foci contained clusters of hepatocytes with variably sized clear cytoplasmic vacuoles resembling fat droplets. These foci of cellular alterations observed in M. cephalus and L. russellii collected from the seaward site of the lagoon could be considered as an intermediate stage in liver tumor development, as they were discrete collections of hepatocytes displaying a typical staining and morphologiocal characteristics as described previously for several species of fish (Boorman et al., 1997; Stentiford et al., 2003; Lerebours et al., 2013). Pre-tumor type conspicuous foci of cellular alterations found in the liver of some M. cephalus and L. russellii species collected from the seaward site of the lagoon might be associated with the high bioavailability of PAHs, especially pyrene type and benzo(a)pyrene type PAHs in fishes collected from the Southern part of the lagoon. PAHs with four or more condensed benzene rings are known to have mutagenic and/or carcinogenic properties (Srogi, 2007).

Histopathological alterations indicate that the health of the fishes inhabiting the lagoon is being threatened due to stress factors including the PAH contaminations in the lagoon. Moreover, the occurrence of lesions in the gills and even more severe lesions in the liver should lead to functional damage to both organs, interfering directly with fundamental processes for the maintenance of homeostasis in these fish. Hence detailed studies on the level of pollutants and health status of the fish species inhabiting this important coastal wetland resource are warranted.

In conclusion, the present study revealed the bioavailability of petrogenic (oil derived) and pyrogenic (combustion derived) PAHs in the Koggala lagoon especially in the seaward site. Further, prominent histological alterations were seen in the gills and liver tissues of the resident fishes in the lagoon. This is the first record of bioavailable PAHs in the Koggala lagoon and the presence of pre-tumor type hepatic lesions in fishes living in Sri Lankan waters. The results of this study provides scientific evidence for the biological impacts in the Koggala lagoon, and calls for further research on coastal water pollution in Sri Lanka in order to develop potential management strategies. Resident fish species in coastal ecosystems can be used as environmental sentinels that can provide early warning signals of potential threats to man.

\section{REFERENCES}

1. Aas E., Beyer J. \& Goksoyr A. (2000). Fixed wavelength fluorescence (FF) of bile as a monitoring tool for polyaromatic hydrocarbon exposure in fish, an evaluation of compound specificity, inner filter and signal interpretation. 
Biomarkers 5(01):9 - 23.

DOI: http://dx.doi.org/10.1080/135475000230505

2. Akaishi F.M. et al. (10 authors) (2004). Morphological and neurotoxicological findings in tropical fresh water fish (Astyanax sp.) after waterborne and acute exposure to water soluble fraction (WSF) of crude oil. Archives of Environment Contamination and Toxicology 46(02): $244-$ 253.

3. Boorman G.A. et al. (10 authors) (1997). Diagnostic criteria for degenerative, inflammatory, proliferative, nonneoplastic and neoplastic liver lesions in Medaka (Oryzias latipes); Consensus of a National Toxicological Programme Pathology working group. Toxicologic Pathology 25(02): $202-210$.

4. Bucke D.(1998). Histology. Methods for the Microbiological Examination of Fish and Shellfish (eds. B. Austin \& D.A. Austin), pp. 69 - 95, Ellis Horwood Limited- Chichester, West Sussex, UK.

5. Central Environmental Authority (CEA) (1995). Wetland Site Report and Conservation Management Plan; Koggala Lagoon. Wetland Conservation Project, Central Environmental Authority/ Arcadis/Euroconsult, Sri Lanka.

6. Dama'sio J.B., Barata C., Munne' A., Ginebreda A., Guasch H., Sabater S., Caixach J. \& Porte C. (2007). Comparing the response of biochemical indicators (biomarkers) and biological indices to diagnose the ecological impact of an oil spillage in a Mediterranean river (NE Catalunya, Spain). Chemosphere 66(07): $1206-1216$.

DOI: http://dx.doi.org/10.1016/j.chemosphere.2006.07.055

7. Fernandes C., Fontainhas F.A., Rocha E. \& Salgado M.A. (2007). Monitoring pollution in Esmoris- Paramos lagoon, Portugal: liver histological and biochemical effects in Liza saliens. Environment Monitoring Assessment 145(1-3): 315 $-322$.

8. FishBase (2014). A Global information system on fishes, version 06/2014. Available at www.fishbase.org, Accessed 13 July 2014.

9. Gunaratne G.L., Norio T., Amarasekara G.P., Priyadarshana T. \& Manathunge J. (2010). Impact of rubble mound groyne structural interventions in restoration of Koggala lagoon, Sri Lanka; numerical modeling approach. Coast Conservation Journal 15(01): 113 - 121.

10. Harshbarger J.C. \& Clark J.B. (1990). Epizootiology of neoplasms in bony fish from North America. Science of the Total Environment 94(1-2): 1 - 32.

11. Hibia J. (1982). An Atlas of Fish Histology; Normal and Pathological Conditions, $1^{\text {st }}$ edition, pp. 147, Kodansha Ltd., Bunkyo-ku, Tokyo, Japan.

12. Insausti D., Maite C., Francesc M., Joan E.C. \& Montserrat S. (2009). Biliary fluorescent aromatic compounds (FACs) measured by fixed wavelength fluorescence (FF) in several marine fish species from NW Mediterranean. Marine Pollution Bulletin 58(11): 1635 - 1642.

13. Jayasiri H.B. \& Wijeratne E.M.S. (2008). Oil dispersion and status of planktonic organisms in Koggala Lagoon. Journal of National Aquatic Resources Research and Development Agency 39: 119.

14. Jernelöv A. (2010). The threats from oil spills: now, then, and in the future. $A M B I O$ 39(5-6): $353-366$.
15. Krahn M.M. et al. (10 authors) (1993). Comparison of high performance liquid chromatography/fluorescence scanning and gas chromatography/mass spectrometry analysis for aromatic compounds in sediment samples after Exxon valdez oil spill. Environmental Science and Technology 27: $699-708$.

DOI: http://dx.doi.org/10.1021/es00041a013

16. Lerebours A., Bignell J.P., Stentiford G.D., Feist S.W., Lyons B.P. \& Rotchell J.M. (2013). Advanced diagnostics applied to fish liver tumours: relating pathology to underlying molecular aetiology. Marine Pollution Bulletin 72 (1): $94-98$.

DOI: http://dx.doi.org/10.1016/j.marpolbul.2013.04.016

17. Leonardi M., Tarifeno E. \& Jeanett V. (2009). Diseases of the Chilean flounder, Paralichthys adspersus (Steindachner, 1867), as a biomarker of marine coastal pollution near the Itata River (Chile): part II. histopathological lesions. Archives of Environment Contamination and Toxicology 56(3): $546-556$.

18. Mohamed F.A.S. (2009). Histopathological studies Tilapia zillii and Solea vulgaris from lake Qarun, Egypt. World Journal of Fish and Marine Sciences 1(1): 29 - 39.

19. Morales-Caselles C., Jim_nez-Tenorio N., Canales G.M.L, Sarasquete C. \& DelValls T.A. (2006). Ecotoxicity of sediments contaminated by the oil spill associated with the tanker "Prestige" using juveniles of the fish Sparus aurata. Archives of Environmental Contamination and Toxicology 51(4): $652-660$.

DOI: http://dx.doi.org/10.1007/s00244-005-0251-0

20. Myers M.S, Landahi J.T., Krahn M.M. \& McCain B.B. (1991). Relationship between hepatic neoplasia and related lesions and exposure to toxic chemicals in marine fish from the U.S. west coast. Environment Health Perspective 90 (January): $7-15$.

21. Picado A, Bebianno M.J, Costa M.H, Ferreira A. \& Vale C. (2007). Biomarkers: a strategic tool in the assessment of environmental quality of coastal waters. Hydrobiologia 587: $79-87$.

DOI: http://dx.doi.org/10.1007/s10750-007-0695-5

22. Pinkney A.E., Harshbarger J.C., Karouna-renier N.K., Jenko K., Skarpheoinsdottir B.L, Lieweborg B. \& Rutter M.A. (2011). Tumor prevalence and biomarkers of genotoxicity in brown bullhead (Ameiurus nebulosus) in Chesapeake Bay. Science of the Total Environment 410 411(December): 248 - 257.

23. Poleksić V. \& Mitrović-Tutundžić V. (1994). Fish gills as a monitor of sublethal and chronic effects of pollution. Sublethal and Chronic Effects of Pollutants on Freshwater Fish (eds. R. Müller \& R. Lloyd), pp. 339 - 352. Fishing News Books, Oxford, UK.

24. Simonato J.D., Guedes C.L.B. \& Martinez C.B.R. (2008). Biochemical, physiological, and histological changes in the neotropical fish Prochilodus lineatus exposed to diesel oil. Ecotoxicology and Environmental Safety 69(1): 112 - 120. DOI: http://dx.doi.org/10.1016/j.ecoenv.2007.01.012

25. Srogi K. (2007). Monitoring of environmental exposure to polycyclic aromatic hydrocarbons: a review. Environment Chemistry Letters 59(4): 169 - 195. 
26. Stentiford G.D., Longshaw M., Lyons B.P., Jones G., Green M. \& Feist S.W. (2003). Histopathological biomarkers in estuarine fish species for the assessment of biological effects of contaminants. Marine Environmental Research 55(2): $137-159$.

DOI: http://dx.doi.org/10.1016/S0141-1136(02)00212-X

27. Teh S.J., Adams S.M. \& Hinton D.E. (1997). Histopathologic biomarkers in feral freshwater fish populations exposed to different types of contaminant stress. Aquatic Toxicology 37(1): $51-70$.

28. van der Oost R., Beyer J. \& Vermeulan N.P.E. (2003). Fish bioaccumulation and biomarkers in environmental risk assessment: a review. Environmental Toxicology and Pharmacology 13(2): $57-149$.

DOI: http://dx.doi.org/10.1016/S1382-6689(02)00126-6

29. Vuorinen P.J. et al. (12 authors) (2006). Use of biliary PAH metabolites as a biomarker of pollution in fish from the Baltic Sea. Marine Pollution Bulletin 53(8-9): $479-487$.

30. Whitfield A.K. \& Elliot M. (2002). Fishes as indicators of environmental and ecological changes within estuaries: a review of progress and some suggestions for the future. Journal of Fish Biology 61(Supplement A): 229 - 250.

31. Zar J.H. (1999). Biostatistical Analysis, $4^{\text {th }}$ edition, pp. 663. Prentice Hall, USA. 